\title{
INDUCTIVE SENSORS FOR BLADE TIP-TIMING IN GAS TURBINES
}

\section{CZUJNIKI INDUKCYJNE DO POMIARU DRGAŃ LOPATEK W TURBINACH GAZOWYCH}

\author{
Radosław Przysowa, Edward Rokicki \\ Instytut Techniczny Wojsk Lotniczych \\ e-mail: radoslaw.przysowa@itwl.pl; edward.rokicki@itwl.pl
}

\begin{abstract}
The paper reviews features and applications of the upgraded inductive sensor for BTT, which is able to operate in contact with exhaust gases of temperature even as high as $1200 \mathrm{~K}$. The new design includes metal-ceramic housing ensuring proper heat transfer, magnetic circuit containing set of permanent magnets with various magnetic field values and Curie temperatures, completely redesigned windings and current/voltage converter used instead of an electromotive force amplifier. Its principle of operation is based on electrodynamical interaction and therefore it may be referred as a passive eddy-current sensor. The sensor technique has been demonstrated on four stages of a surplus military turbofan including the high pressure turbine as part of the engine health monitoring system. We present signal samples and review methods used for online processing of time-of-arrival signals when only a limited number of sensors is available.
\end{abstract}

Keywords: blade vibration, tip-timing, structural integrity, eddy-current sensor

Streszczenie: $W$ publikacji opisano cechy $i$ zastosowania ulepszonego czujnika indukcyjnego do pomiaru drgań topatek wirnikowych, który jest $w$ stanie działać $w$ kontakcie z gazami spalinowymi o temperaturze osiagajacej $1200 \mathrm{~K}$. Whętrze czujnika chronione jest przez ceramiczny ekran i metalowa obudowe, zapewniaja prawidlowe odprowadzanie ciepła. Obwód magnetyczny zawiera zestaw dwóch magnesów trwatych o różnych wartościach pola magnetycznego i temperatury Curie, calkowicie przeprojektowane uzwojenia oraz konwerter prąd / napięcie, stosowany zamiast wzmacniacza sity elektromotorycznej. Zasada dziatania uktadu opiera sie na interakcji elektrodynamicznej i dlatego może być nazywany pasywnym czujnikiem wiropradowym. Czujniki tego typu zastosowano $w$ czterech stopniach wojskowego silnika dwuprzepływowego, w tym turbinie wysokiego ciśnienia, jako część systemu monitorowania stanu technicznego silnika. Zaprezentowano przykłady sygnału pomiarowego oraz metody stosowane do przetwarzania danych od topatek $w$ czasie rzeczywistym w układzie, w którym stosuje się ograniczona liczba czujników.

Stowa kluczowe: drgania topatek, bezdotykowy pomiar drgań topatek, trwatość, czujnik wiropradowy 
Inductive sensors for blade tip-timing in gas turbines

Czujniki indukcyjne do pomiaru drgań topatek $w$ turbinach gazowych

\section{Introduction}

Non-contact blade vibration measurement became a significant technique for ensuring structural integrity of jet engines and stationary turbines. The method, called blade tip-timing (BTT) or Non-contact Stress Measurement System (NSMS) uses several sensors mounted circumferentially to precisely determine temporary positions of each blade tip in every single rotation. Temperature resistant tip-timing sensors for gas turbines belong to priority research objectives both in the USA [1] and in Europe [2].

Magnetic sensor technologies are widely used to measure rotational speed or wheel's position [2]. Eddy-current, inductive, Hall or GMR [10] probes typically operate below $60^{\circ} \mathrm{C}$ and experience serious performance problems in elevated temperature. The inductive sensor, known also as speed pickup or Variable Reluctance (VR) sensor has been used for blade tip-timing in compressors and steam turbines since late 1940 s, usually in the low-pressure section (up to $80^{\circ} \mathrm{C}$ ). In the environment of a gas turbine, with temperature over $600^{\circ} \mathrm{C}$, the classic inductive sensor cannot operate.

In standard design the permanent magnet generate a magnetic field in front of the sensor face. The measurement signal is generated as the electromotive force in the sensor's coil as a result of the blade's motion changing the reluctance of the magnetic field. Weak voltage signal is available at the output, especially at low speeds. This issue is usually solved by increasing the number of coil turns. Higher temperature decreases magnetization of the permanent magnet and increases the impedance of the windings, which affects the amplitude and the bandwidth of the output signal.

\section{Sensor overview}

The upgraded inductive sensor includes a low-impedance coil with a limited number of turns. The coil with the current - voltage converter is a short circuit. The short circuit current is the source of the secondary magnetic field, which counteracts the interference of the permanent magnet field caused by a passing blade. The instantaneous intensity of this current reaches such a value that the induced field compensates the impact of the blade. The current flowing in the coil circuit describes the motion of the blade tip [4].

When a passing blade is made of non-ferromagnetic conductive material it also interferes the magnetic field with its weak eddy-currents. The interaction is detectable by the short circuit coil and the adjusted current - voltage converter.

This design minimizes the influence of external electromagnetic interference due to the input impedance near zero. A small number of turns has a positive effect on the frequency response of the sensor, removing resonances to high frequencies. Amplitude of the output signal depends on rotational speed. The interaction between the sensor and the blade is described by electrodynamic moments of currents flowing in the coil and the blade [5]. 
The sensor comprises ceramic head, steel body and electromagnetic circuit (Fig. 1). The current - voltage converter is enclosed in the driver, powered with $+5 \mathrm{~V}$ DC voltage, connected to the sensor with a cable up to 12 meters. The output signal is sampled or triggered in a data acquisition hardware and then analysed with software.

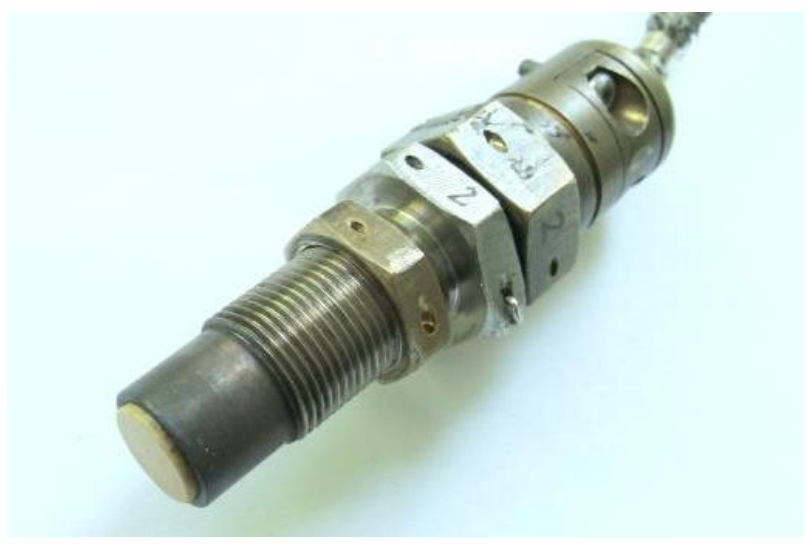

Fig. 1. The sensor after 60 hours testing in the a gas turbine

\section{Blade Health Monitoring}

More and more interest in blade health monitoring is observed recently, as it allows to maintain legacy turbines, whose blades were designed before implementation of CAD systems. It is usually safe and efficient to start monitoring poorly designed blades, instead of cancelling or redesigning the machine. In aero-engines fan blades vibration monitoring is performed also to early detect foreign object damage and to mitigate FOD-initiated HCF cracks.

Online health monitoring may be a method for damage-tolerance maintenance [19] also for modern blade designs, ensuring turbine operation up to material endurance limits.

ITWL has been developing and using inductive tip-timing sensors for almost 30 years. Several tailored designs have been developed for sensing compressor and turbine blades made of ferromagnetic and non-ferromagnetic materials, offering resolution about 20um. They were applied in:

- All stages of compressor and turbine of SO-3 turbojet [11][13][17]

- Fan stage of K-15 turbojet

- Military turbofan - fan, compressor, HPT, LPT [7]

- 1st stage of Spey turbofan tested in spin pit in Patuxent River [14]

- Industrial fan in the desulphurization system in a convention power plant [16] Inductive sensor is the first choice technology for health monitoring applications due to long life, high reliability and resistance to contamination. 
Inductive sensors for blade tip-timing in gas turbines

Czujniki indukcyjne do pomiaru drgań topatek $w$ turbinach gazowych

On the other hand optical fibre probes are primarily used in development testing as they offer higher spatial resolution required to study higher order modes.

The described technology has been used to design sensors for a four stages of a military turbofan, including High Pressure Turbine (HPT). The access to blade tips is very limited and fitting of the sensor was challenging (Fig. 2). Gas temperature in this engine section is about $1100^{\circ} \mathrm{C}$. The sensor is passively cooled with bypass air. Expected tip deflections are below $0.05 \mathrm{~mm}$ and required spatial resolution of the sensor cannot be provided by the coil with a traditional winding.

The developed sensors passed 40 hours of turbofan test-runs, providing signals (Fig. 3 and 4) applicable to tip-deflection measurement (Fig. 5). Signal characteristics and actual sensor performance will be reviewed.

Bench test runs showed that the developed system components are working properly, but it was not clear how long it would take to bring the system to the operational readiness. In the original design of the turbofan there are no slots for blade tip sensors. Most of the probes are located in areas with difficult access and their replacement is not possible without disassembling the engine.

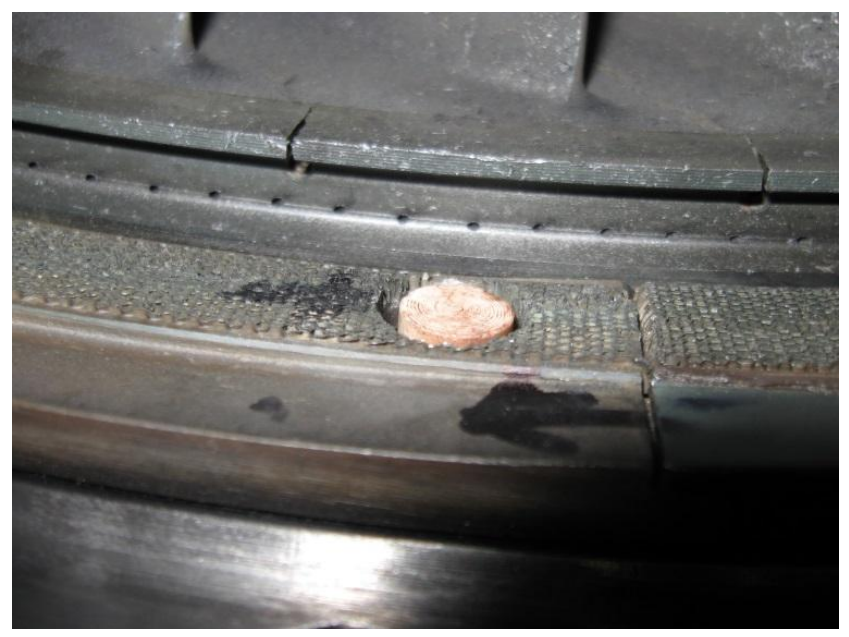

Fig. 2. Ceramic head of the sensor fitted into the casing of HPT

Selected probe placement was a compromise between available space and the possibility of obtaining a clear signal. As a result, the sensors in the fan and the compressor, instead of in the middle of the chords were located near the trailing edge of the blades. This made the proper arming of the trigger more difficult, both at idle and at maximum range, particularly in the case of the fan.

The test system overcame this issue and obtained a set of correct signals from the turbine, compressor and fan, but the margin of error was quite narrow and in certain conditions the triggering could fail as in previous attempts. 


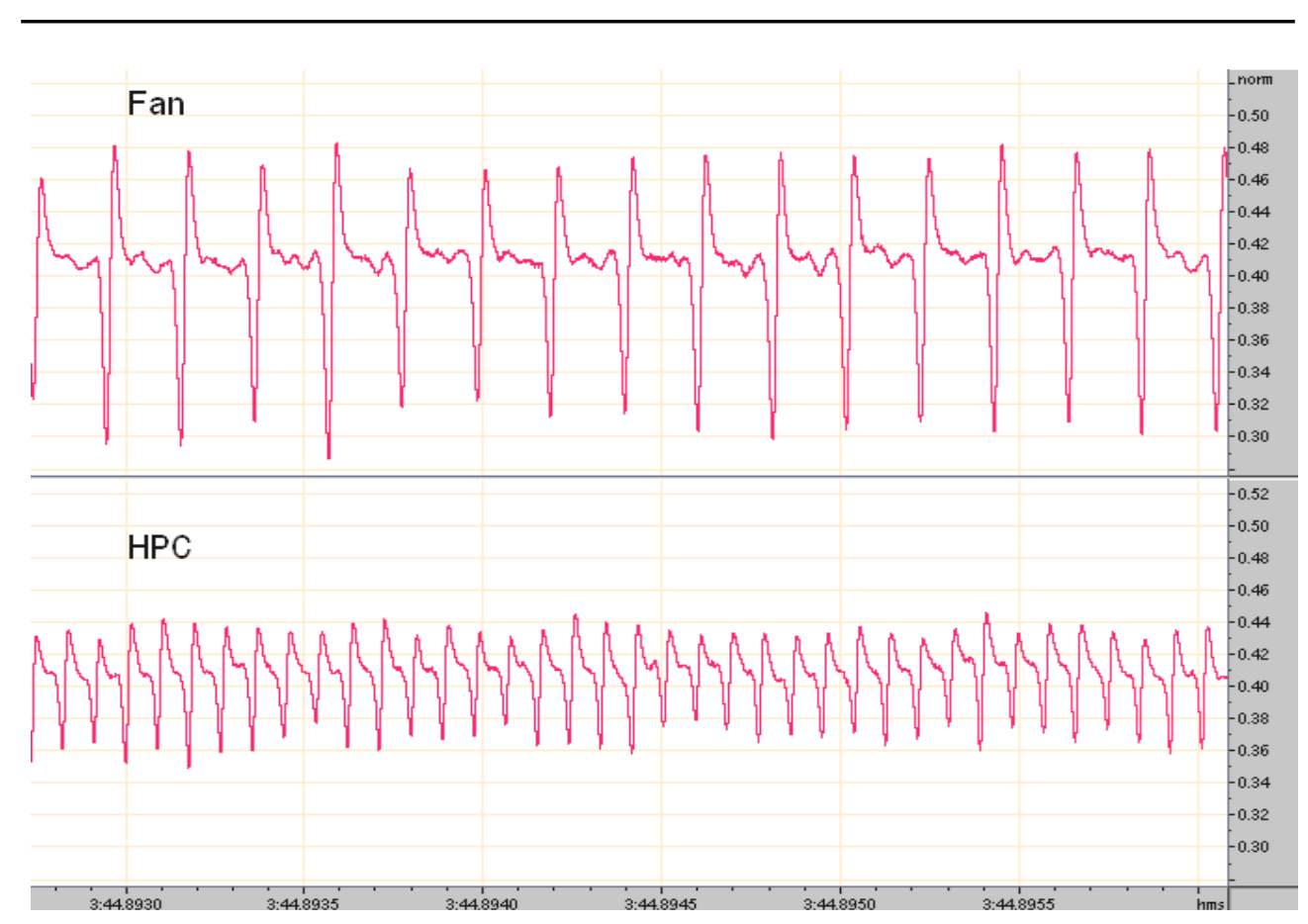

Fig. 3. Fan and compressor sensor output signal sampled at take-off speed

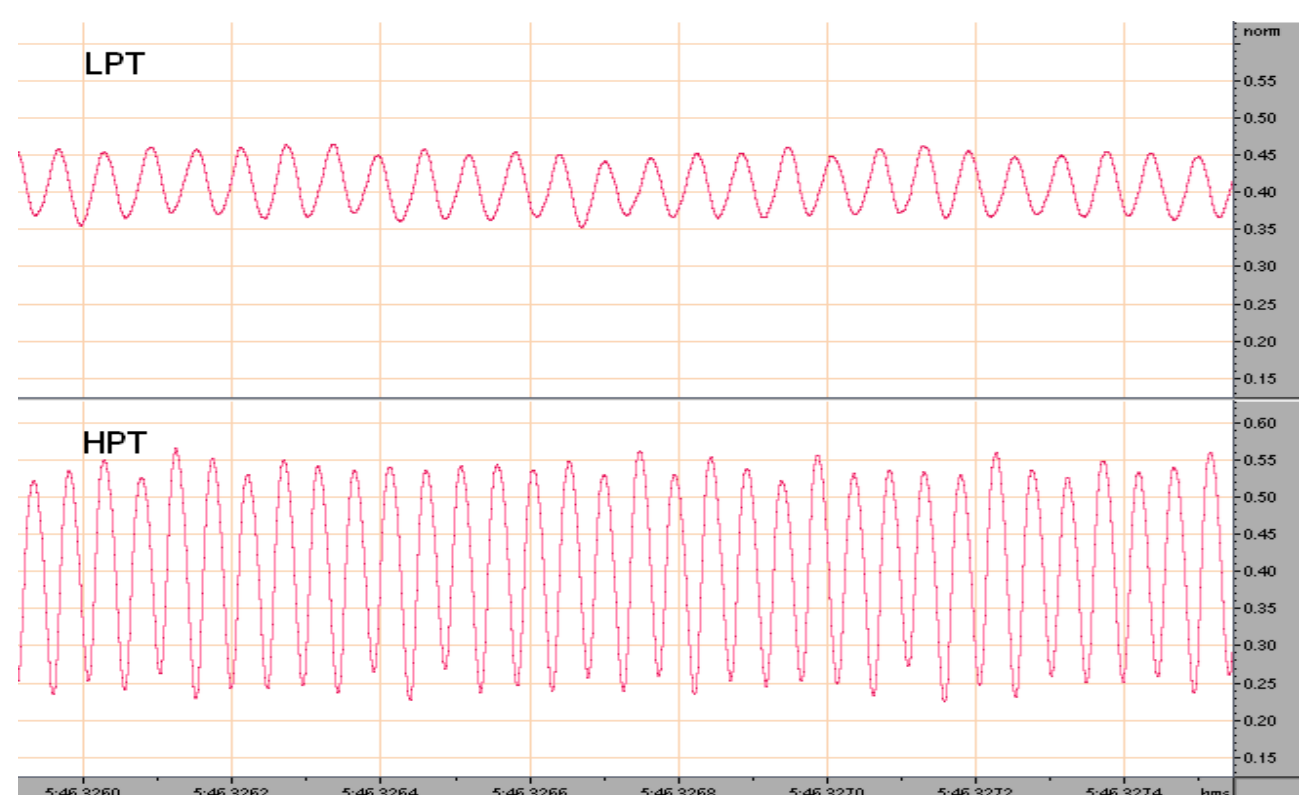

Fig. 4. LPT and HPT sensor output signal sampled at take-off speed 
Inductive sensors for blade tip-timing in gas turbines

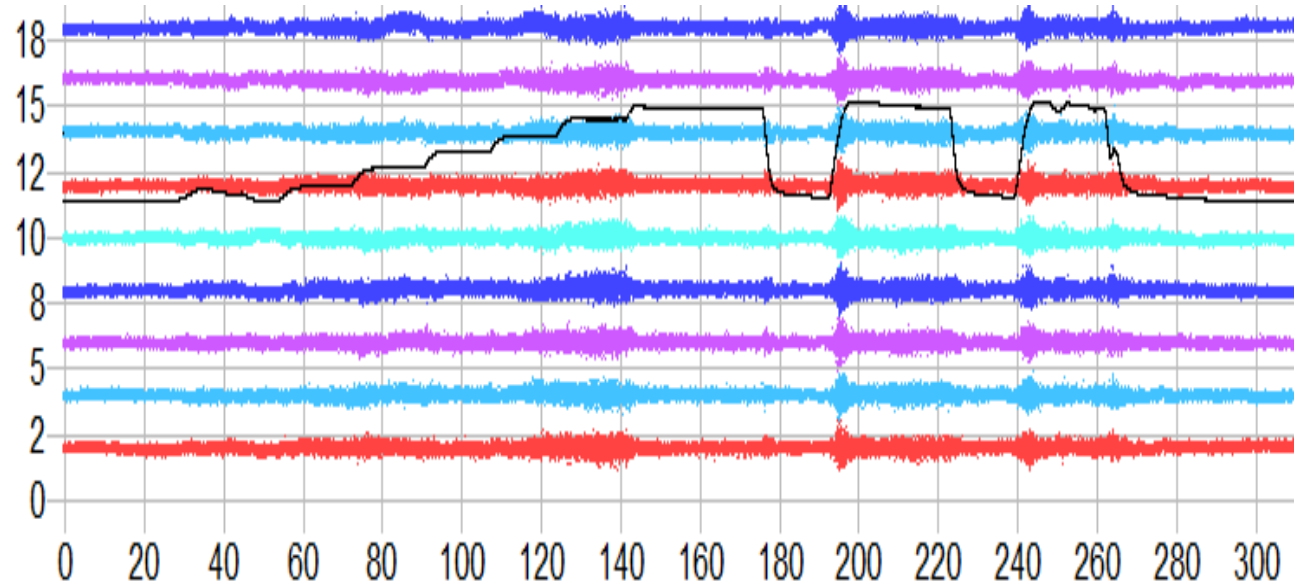

Fig. 5 Blade deflection of HPT in a function of time

\section{Data Analysis Methods}

The analysis of blade vibration should provide:

- Vibration parameters of individual blades such as frequency, amplitude and phase;

- Characterization of bladed disk vibration - nodal diameter, frequency, amplitude and phase;

- Identification of resonances - to determine vibration mode, speed and engine order;

- Indication of the blades, which differ from the baseline e.g. high responding blades;

In health monitoring / prognostic system the measured vibration parameters are compared with reference values defined in accordance with physical material properties [19]. The symptoms of improper operation of the blades include:

- High level vibration, resulting from the operation in resonance, reduced the damping factor of the system, or the occurrence of a large exciting force,

- Reduction in the frequency of fundamental mode, associated with the development of a fatigue crack,

- Altered static position of a blade on the circumference visible as distortion of the stack pattern (Fig. 6).

Material properties and validated components' models are required to establish reliable baseline data and threshold values required to be able to detect upcoming failure, raise alarms and suggest appropriate actions. 


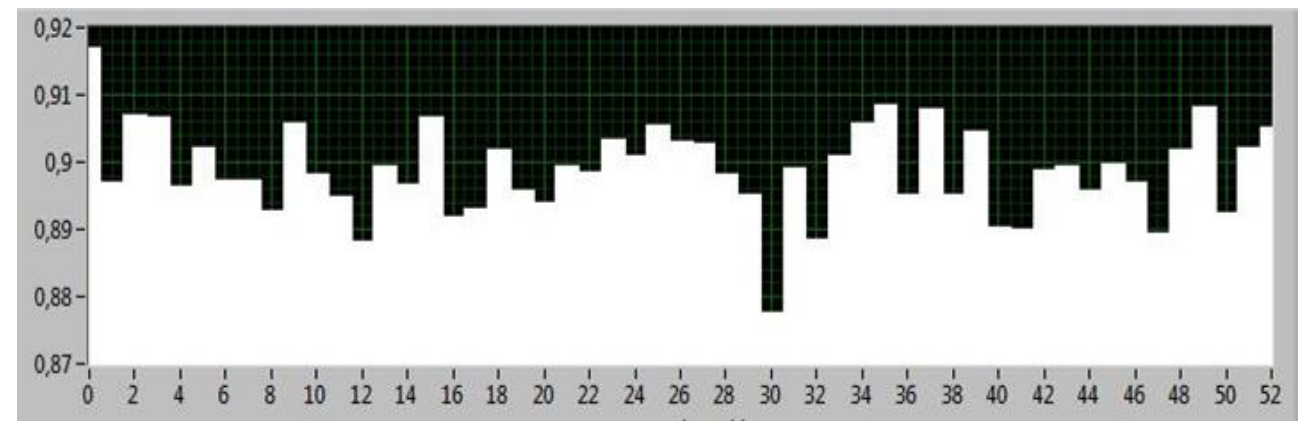

Fig. 6. Example of stack pattern for a single sensor

It is very unlikely to be able to install sensors in operational engines in quantities typical for development testing for several reasons. The weight of the added equipment is limited in aerospace applications. Inductive probes, especially in high temperature versions are larger than optical. There is little space over blade tips in existing structures and you can expect conflicts with installations such as guided vanes, turbine cooling and flanges.

Development tests usually require 6-9 sensors to measure blade vibration of a stage. Three sensors in one plane is a minimum to fit the observations of the oscillator model. ITWL's installations in systems and related demonstration tests include typically 1-4 sensors per stage, sometimes 8 , even though our data acquisition system can handle 32 channels.

Configuration with a reduced number of sensors is not suitable for the characterization of blade vibration as it features elevated uncertainty of measurement and requires prior knowledge of vibration spectrum to avoid misidentification of modes or excitation orders.

The following sections discuss analysis methods of TOA signal we use in single or dual sensor systems. Many of presented concepts were implemented in the software of SPL-1b system in mid 1990s' [11], [17].

\section{Reference Signal}

BTT systems apply one-per-revolution (OPR) sensor to identify (number of) blades and define their expected time of arrival (window). OPR pulses are also used as the reference for data conversion from stationary to rotating reference frame (table 1).

OPR probe is a quite costly component of the system and is rarely available in operational aero-engines. It also introduces significant uncertainty into vibration measurement. In some cases it is possible to make it redundant using reference signal derived from tip-timing sensors [11], [18]. Alternatively, TOA data from different tip sensors can be analysed in pairs as differential deflections [20].

If OPR sensor is unavailable, you can identify blades using the blade spacing (stack pattern), which is specific to the disk. It illustrates the natural variation of the tip geometry as seen by the sensors. The sequence of blade spacing in the measurement can be correlated with the reference pattern. 
Inductive sensors for blade tip-timing in gas turbines

Czujniki indukcyjne do pomiaru drgań topatek $w$ turbinach gazowych

Table 1. Example of alignment of raw BTT data

\begin{tabular}{|c|c|c|c|}
\hline OPR & sensor 1 & sensor 2 & sensor $n$ \\
\hline $\mathrm{t}_{10}$ & $\mathrm{t}_{11}$ & $\mathrm{t}_{\mathrm{m} 2}$ & $t_{m-1, n}$ \\
\hline $\mathrm{t}_{20}$ & $\mathrm{t}_{21}$ & $\mathrm{t}_{12}$ & $\mathrm{t}_{\mathrm{mn}}$ \\
\hline $\mathrm{t}_{30}$ & $\mathrm{t}_{31}$ & $t_{22}$ & $\mathrm{t}_{1 \mathrm{n}}$ \\
\hline $\mathrm{t}_{40}$ & $\mathrm{t}_{41}$ & $t_{32}$ & $t_{2 n}$ \\
\hline$t_{50}$ & $\mathrm{t}_{51}$ & $\mathrm{t}_{42}$ & $t_{3 n}$ \\
\hline$t_{60}$ & $\mathrm{t}_{61}$ & $\mathrm{t}_{52}$ & $t_{4 n}$ \\
\hline $\mathrm{t}_{70}$ & $\mathrm{t}_{71}$ & $\mathrm{t}_{62}$ & $t_{5 n}$ \\
\hline $\mathrm{t}_{80}$ & $\mathrm{t}_{81}$ & $\mathrm{t}_{72}$ & $t_{6 n}$ \\
\hline $\mathrm{t}_{90}$ & $t_{91}$ & $t_{82}$ & $t_{7 n}$ \\
\hline
\end{tabular}

\begin{tabular}{|c|c|c|c|c|}
\hline blade\# & sensor 1 & sensor 2 & $\cdots$ & sensor $\mathrm{n}$ \\
\hline 1 & $\delta_{11}$ & $\delta_{12}$ & $\ldots$ & $\delta_{13}$ \\
\hline 2 & $\delta_{21}$ & $\delta_{22}$ & $\ldots$ & $\delta_{23}$ \\
\hline 3 & $\delta_{31}$ & $\delta_{32}$ & $\ldots$ & $\delta_{33}$ \\
\hline & & & $\ldots$ & \\
\hline $\mathrm{m}-1$ & $\delta_{\mathrm{m}-1,1}$ & $\delta_{\mathrm{m}-1,2}$ & $\ldots$ & $\delta_{\mathrm{m}-1,3}$ \\
\hline $\mathrm{m}$ & $\delta_{\mathrm{m} 1}$ & $\delta_{\mathrm{m} 2}$ & $\ldots$ & $\delta_{\mathrm{m} 3}$ \\
\hline
\end{tabular}

\section{Measurement of Time-of-Arrival}

The classic tip-timing method uses only one datum per the pulse generated by sensor for each blade pass. It is typically zero-crossing time and is provided by the analogue triggering circuit or alternatively measured by numerical processing of sampled sensor signal.

The phase of generated pulses known as time-of-arrival carries information about the instantaneous position of the blade. Uncertainty of TOA measurement directly affects the analysis results. TOA is measured by triggering circuits also known as phase detectors. As the inductive sensor generates differentiated pulses with a steep falling edge (Fig. 7) it is possible to use standard industrial zero crossing detectors. They produce a digital TTL signal, accepted by digital circuits such as ASIC and FPGA, which implement counters to measure periods.

Systems of this type have limitations specific to analogue circuits and it is difficult to adapt their structure to signals with pulses of different shapes that are generated by blades made of different materials. The alternative approach using high frequency sampling and digital processing of the signal is increasingly being used even in embedded systems. 
Digital discriminator implemented in software replaces the analogue trigger circuit and a counter card, reducing the measurement channel to the sensor, amplifier and AC converter card.

The proposed zero crossing detector is triggered only for the pulses of a certain amplitude, which prevents distortion of the results by noise in the input signal. Further, the possibility to adapt the detector to the mean pulse amplitude is preferred, due to the dependence of the signal level of the rotor speed characteristic of the inductive sensor.

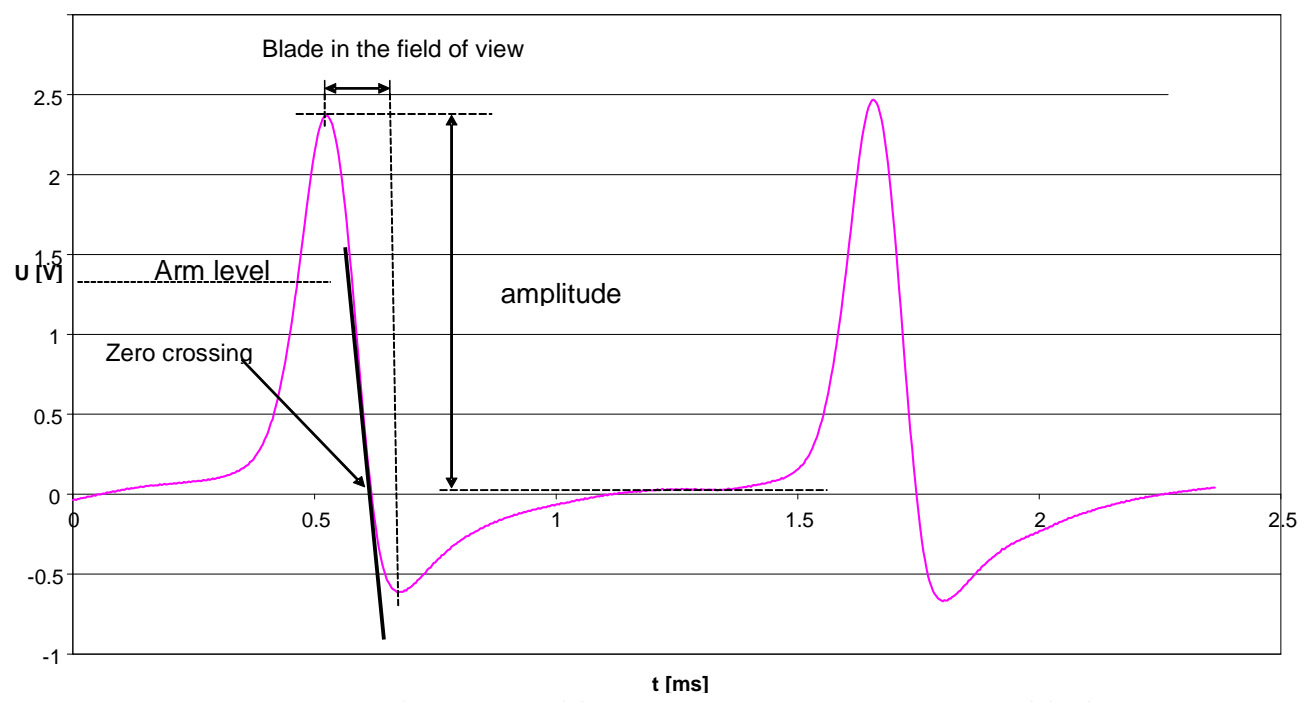

Fig. 7. Signal generated by ferromagnetic compressor blade

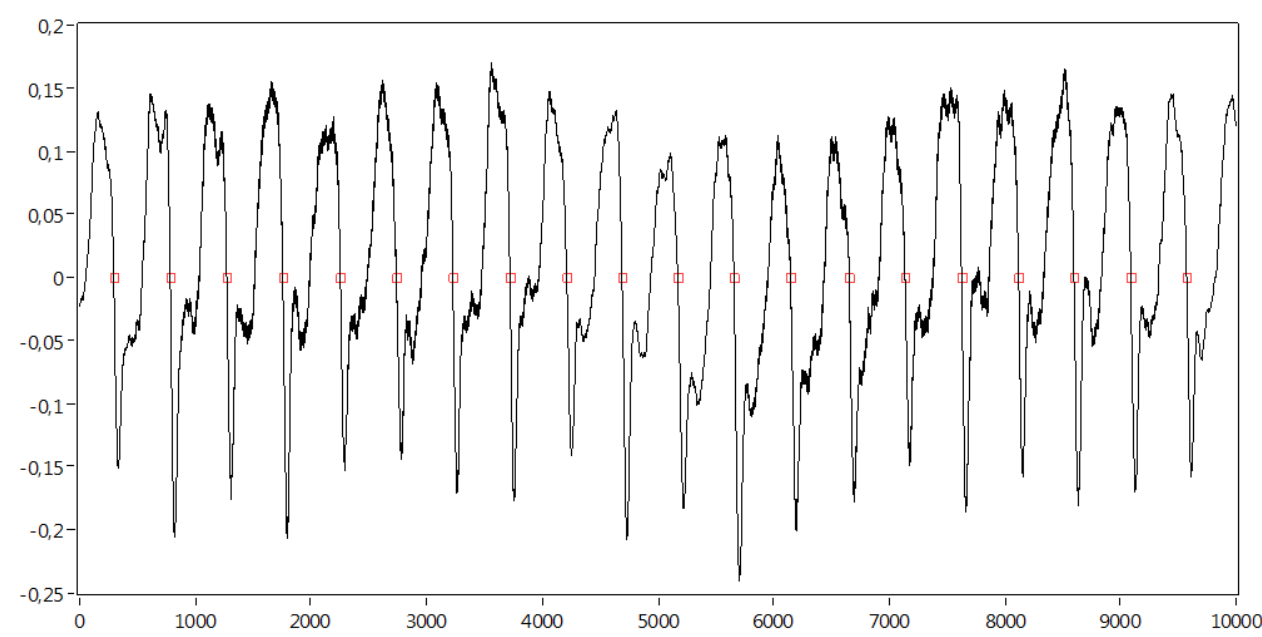

Fig. 8. Signal generated by titanium fan blades and results of software triggering $s$ 
Inductive sensors for blade tip-timing in gas turbines

Czujniki indukcyjne do pomiaru drgań topatek $w$ turbinach gazowych

We implemented the detector in form of a state machine (Fig. 9). In the unarmed state it waits for a pulse from the blade tip, comparing samples with a threshold value. When it is crossed, the machine goes to the armed state. In this state, it passes through the maximum of the pulse until it encounters the first sample with a negative value. Then the machine records the time of zero-crossing and goes again to unarmed state. Noise and parasitic pulses should not arm the discriminator.

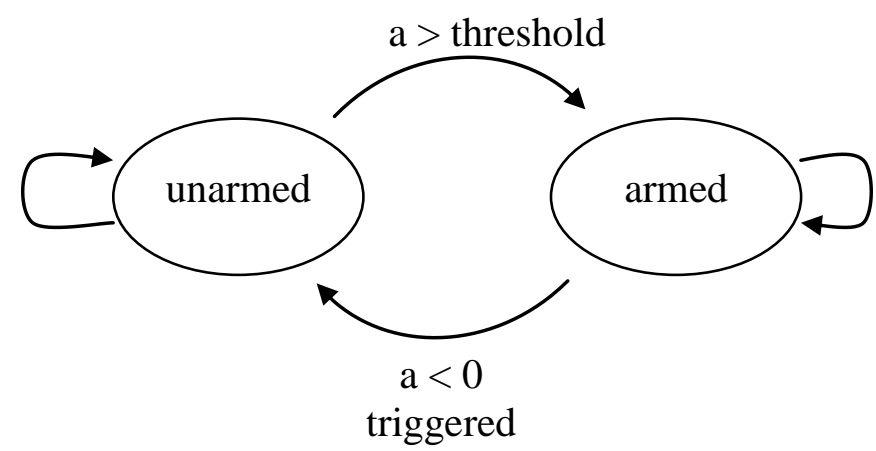

Fig. 9. Digital zero-crossing detector as a state machine

In the simplest approach, a constant arming threshold can be assumed, which is equal to e.g. half of the expected signal amplitude. In practice, as output signal of an inductive sensor depends on rotational speed, you may have to adjust the arming threshold to the actual signal level.

Zero-crossing times are generated by the digital detector. To improve the resolution of time measurement, we calculate the zero-crossing from the triangle using the last sample with a positive value and the first one with a negative one (linear interpolation).

Most gas-turbine blades generate pulses without the falling edge (Fig. 4) and we have to measure the peak value with the polynomial interpolation [5] or alternatively trigger on both edges of pulse and take their mean value.

\section{Missing and Extra Blades}

Errors of this type are usually a result of a momentary interference, but may also reflect defects of the sensor or the conditioning circuit (Fig. 10). If you lost a few blades a time it is best to omit data from the rotation. If data is corrupted in many revolutions the dataset cannot be repaired and analysed.

The trigger may malfunction at a low level signal from the blades. The so-called "missing" blades happen as a result of the loss of a single measurement. It also involves a shift of the position of subsequent data. The error of this type usually is easily detected and repaired. The datum can be replaced with the one taken from previous rotation. If one blade is often lost and other are captured properly at the same time, it means that its tip is not sensed properly for some reason.

Similarly, "extra" blades are produced by spikes in the signal or by other factors related to triggering and should be detected and ignored. 
Undetected missing and extra blades interfere statistics calculated from data such as mean and standard deviation. It is better to use median or median filter instead, which unlike the arithmetic mean are resistant to outliers.

\section{period $[\mathrm{s}]$}

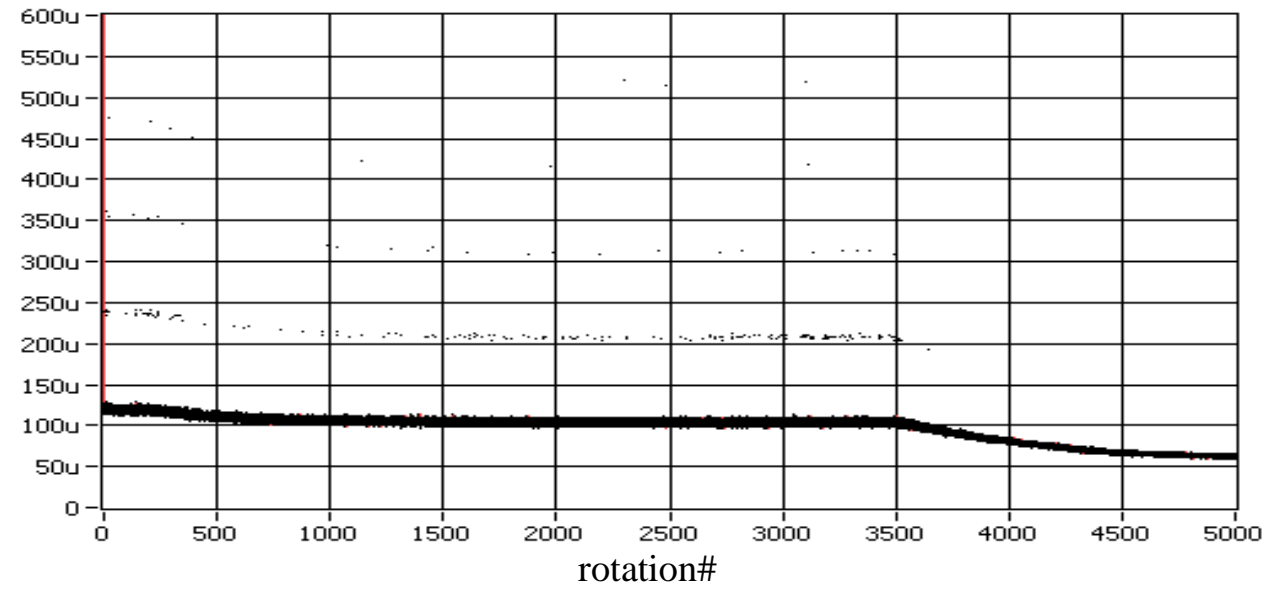

Fig. 10. Example of a corrupted period signal with numerous missing blades

\section{Monitoring of Blade Amplitude}

Monitoring of blade vibration requires a single tip sensor and the reference OPR sensor or alternatively a pair of tip sensors to be able to subtract their indications in order to convert them into the deflection of blade tips in the rotating reference frame. Tip deflection in successive rotations, observed as a point cloud, is the aliased displacement signal of blade vibration. It is assumed that the envelope of tip deflection equals the amplitude of asynchronous vibration. On the other hand, a quasi-static deviation toward the equilibrium position, observed during a change of the rotational speed, is associated with crossing the synchronous resonance.

In the preliminary vibration assessment we use tip displacement charts in form of a point cloud, which can be displayed even during measurements (Fig. 5). They are plotted in a function of time or rotational speed for a selected sensor. The graphs show amplified tip displacement toward the static position. Increased peak-peak amplitude related to non-integral vibration is observed as a point cloud.

When speed is changed charts demonstrate resonances as "zigzags" because vibration is synchronized with sampling (Fig. 10). Low-pass filtering of the signal improves resonance visibility. Furthermore, the bar plot is used to monitor peak-topeak amplitude of blades.

Our systems monitor values of blade tip deflection and compares them with the threshold line defined as a function of the rotational speed. Digital filters or statistics such as the mean or median value and the standard deviation calculated successively for a number of rotations help to characterize the data and remove spikes and outliers. Safety limits are defined as a result of the structural analysis and prior testing. 
Inductive sensors for blade tip-timing in gas turbines

Czujniki indukcyjne do pomiaru drgań topatek $w$ turbinach gazowych

SNDŁ-1b monitoring system for TS-11 trainer operates without a microprocessor and with its logic circuit it is able to detect excessive blade vibration in the selected speed range, record the event and warn the pilot. Recent designs of BHM systems include microcontrollers or an FPGA logic because their diagnostic algorithms watching responses of higher orders than $\mathrm{EO} 2$ have to be more complex.

Here is the list of typical tasks in a monitoring system:

- Convert TOA data to the rotating frame reference,

- Verify data alignment and blade numbers,

- Detect and correct extra/missing blades,

- Filter out the static signal component,

- Estimate amplitude and frequency of vibration,

- Compare values with the baseline,

- Store selected results,

- Count exceedance and rise alarms.

To avoid false alarms we count exceedances and require several rotations with excessive vibration to rise them. The counter increments when the reference level is crossed. Otherwise it decrements up to zero. The warning light (yellow) and the alarm light (red) are turn on when their counters reach their threshold on the basis of hysteresis.

\section{Integral Responses}

Tip-timing system provides aliased (undersampled) tip deflection signals. Singlesensor data is insufficient to measure real amplitude of integral responses, which are observed when the driving force $\mathrm{F}(\mathrm{t})=\mathrm{F}_{0} \cos (2 \pi f \mathrm{t})$ is synchronous with the rotation:

$$
f=\operatorname{EO} f_{\mathrm{r}} \text {, where } f \text { - vibration frequency, } f_{r} \text { - rotational frequency. }
$$

In this case tip deflection $y_{i}(\omega)$ is a time-independent speed function, related to angular sensor position (Fig. 10). The integral response is synchronized with the measurement and belongs to a low-frequency (static) component of the signal which is obtained by averaging or low-pass filtering of the data for each blade over some revolutions. Various Finite Impulse Response filters can be applied, but Savitzky-Golay is recommended [21]. The vibratory data that remains after subtracting the static deflection is considered as a non-integral response.

During deceleration of the rotor, characteristic phase change (zigzag) is observed while passing resonance. First generation single-sensor tip-timing systems located these zigzags to measure resonance speed and peak-peak amplitude. This technique, known as Zablotskiy method, works only for low-order, high-amplitude resonances, lacks accuracy and is relatively difficult to be automated.

During synchronous vibration tip deflection is measured in phase with the excitation force, not only in the resonance:

$$
E O \alpha_{i}=2 \pi f t_{i}
$$

$t_{i}$ - time of blade arrival to the sensor $i$, installed at the angle $\alpha_{i}$ 
This is why time can be eliminated from the oscillator solution:

$$
y_{i}=A(\omega) \cos \left[E O \alpha_{i}+\phi\right]
$$

Approximate resonant frequencies and engine orders exciting blade vibratory modes are usually known from previous measurements and FEM analysis and presented on Campbell diagram. Using this information engine orders can be assumed to determine the frequency, amplitude and phase of the observed responses with linear least-square method. Observations of several sensors for a single rotation are fitted to the equation of vibration in the form [20], [22]:

$$
y_{i}=a \sin E O \alpha_{i}+b \cos E O \alpha_{i}+c
$$

In this case the fitting is linear and well-conditioned when sensors are properly distributed on the circumference. The static component of evaluated signals should be corrected prior to fitting in the process known as zeroing [22].

The amplitude and phase can be calculated from the fitting result a and $b$. The resonance frequency $\mathrm{f}_{0}$ is proportional to the rotational speed, at which the highest amplitude is observed and the phase crosses zero:

$$
f_{0}=E O n_{0} / 60
$$

At least $2 \mathrm{~N}+2$ sensors are required to measure $\mathrm{N}$ simultaneous responses.

Without the prior knowledge of the blade vibration characteristics there is high risk of assuming an inappropriate model or incorrect EO when fitting data in 3- or 4sensor systems.

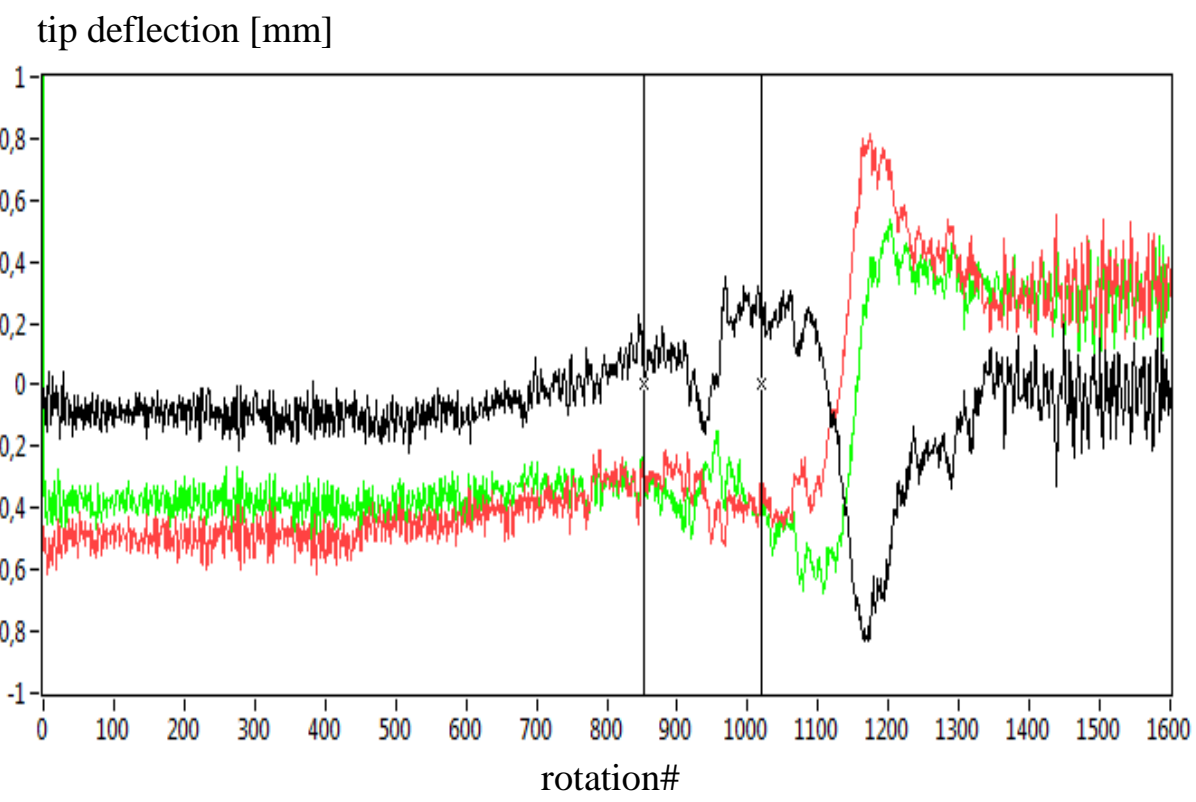

Fig. 10. Passing through two resonances - deflection of the blade's tip, observed by 3 sensors 
Inductive sensors for blade tip-timing in gas turbines

Czujniki indukcyjne do pomiaru drgań topatek $w$ turbinach gazowych

\section{Stress Estimation}

Blade model using Finite Element Method (FEM) is developed to determine natural vibration frequencies and mode shapes. The model based on analyses can provide relations between stress levels and the tip deflection.

Calibration of the FEM model is based on strain and tip-deflection measurement, performed on a blade shaker (Fig. 11), a spin facility with a blade excitation installation or an instrumented engine. The experiment should confirm the modal shapes and provides the relationship between the measured tip-deflection and the indication of strain gauges placed at critical points in the blade. For higher forms of vibration deflection measurement is effective only in certain locations such as the trailing edge, in the middle of the blade span.

The tip-timing system uses Stress/Deflection ratios generated by the calibrated FE model to estimate the stress distribution in the selected critical points or throughout the whole blade and compare it with material endurance limits [19].

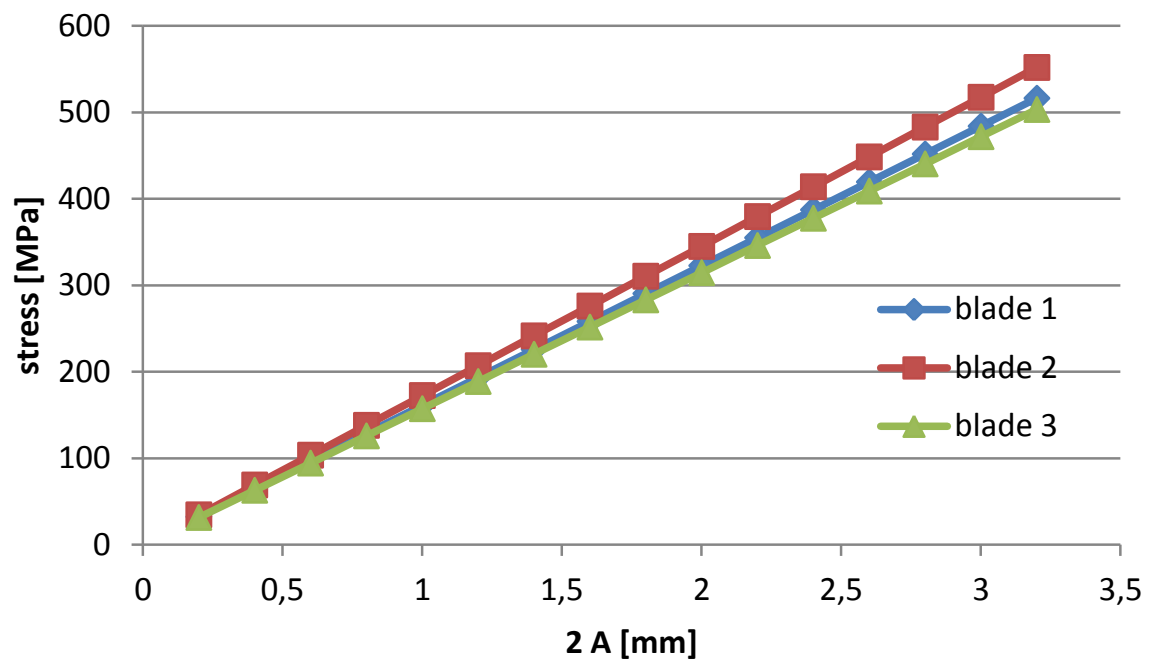

Fig. 11. Relation between stress and the tip deflection measured on the shaker for the first mode

\section{Single blade spectrum}

Deflection of the single blade in successive rotations can be analysed with Fast Fourier Transform. You can measure the fractional frequency and the amplitude of asynchronous vibration occurring during compressor surge, rotating stall or blade flutter. With one sensor the bandwidth is limited by half of the rotational frequency $(1 / 2$ EO). Any components with higher frequencies are presented as aliases, so the spectrum requires reconstruction to measure the real frequency of blade vibration. 
The resolution of frequency measurement depends on width of the window, which should include stationary or quasi-stationary data. The frequency resolution achievable with FFT in transient operations is unsatisfactory due to relatively rapid changes of rotational speed in military engine. It can be improved by adding the signal of an additional sensor as imaginary (quadrature) component of time domain representation.

The graph shows the logarithmic power spectral density change during the deceleration of the selected blade in the bandwidth from 0 to the half the rotational speed ( $1 / 2$ EO) obtained by Short Time Fourier Transform (Fig. 12). We plot the rotation number instead of time on $\mathrm{x}$ axis and engine order instead of frequency on $y$ axis to maintain constant resolution.

Accuracy of the spectral peak estimates is limited due to single-blade spectrum features such as low signal-to-noise ratio, low resolution and aliasing. However the method can be used in a monitoring system to track changes of vibration frequency. It is confirmed that the fundamental frequency decreases when a fatigue crack is initiated and developed [11], [13], [17].

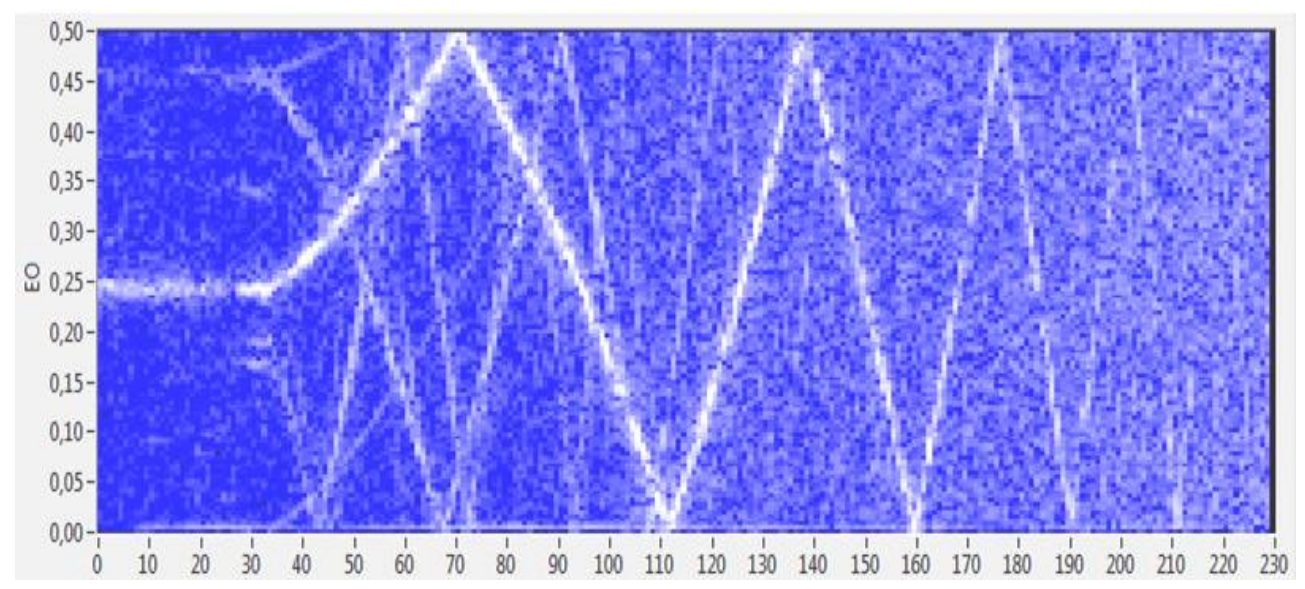

Fig. 12. single blade spectrum for the run-down of a steam turbine

\section{All-Blade Analysis}

Asynchronous vibration such as flutter, rotating stall or surge engage the whole bladed disk rather than individual blades and therefore all-blade spectrum is a preferred method to observe them. The spectrogram (Fig. 13) can be generated even online by taking successively tip deflection data from several rotations to the FFT window. When deflections of all blades are transformed together the sampling rate is increased by the number of blades $b$ and the bandwidth is equal $1 / 2 \mathrm{EO} b$. 
Inductive sensors for blade tip-timing in gas turbines Czujniki indukcyjne do pomiaru drgań topatek $w$ turbinach gazowych

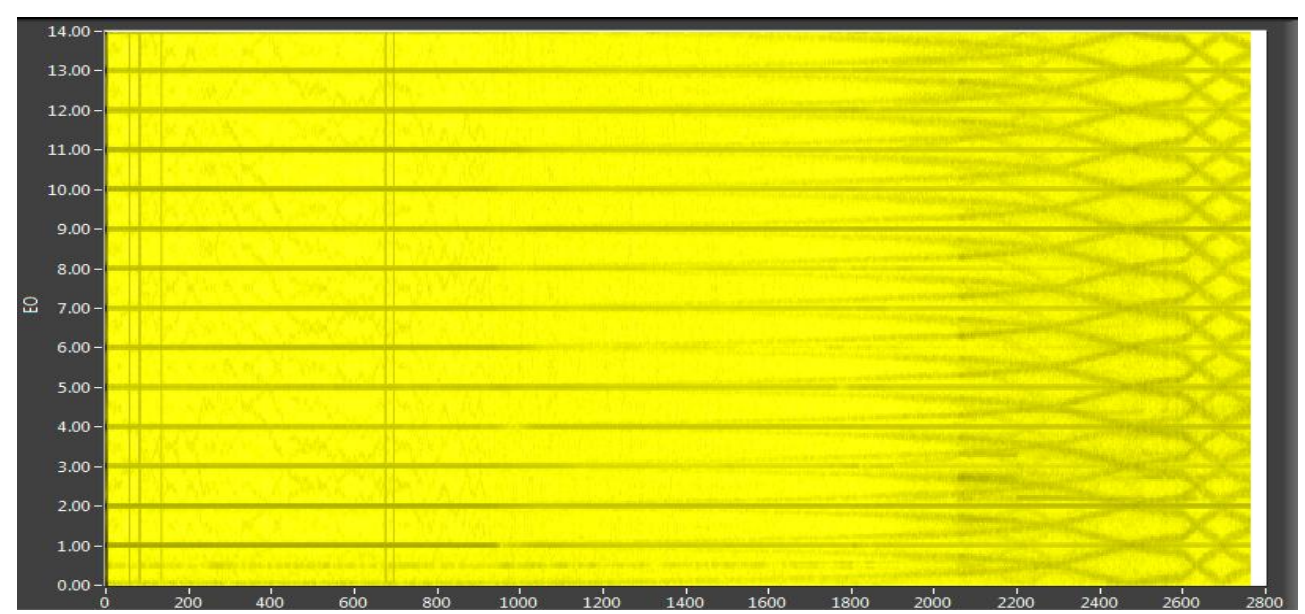

Fig. 13. All-blade spectrum for the fan stage of a turbojet

The all-blade analysis considers the bladed disk as a unified vibrating assembly and assumes it vibrates in nodal diameter modes. Due to circular symmetry, the nodal diameter modes occur in orthogonal pairs that become traveling waves as a result of rotation. Two sensors with known angular separation are required to measure nodal diameter. Amplitude, phase and frequency of response can be found in the Fourier spectrum.

\section{Summary}

The redesigned inductive sensor enables to measure deflection of a blade tip even in gas turbines in engine health monitoring systems. Test-runs has verified sensor robustness and resistance to high temperature and contamination.

Health monitoring applications of tip-timing include less sensors than typical design verification tests in engine development programmes, which increases the uncertainty and makes the analysis more difficult. Data processing methods are similar in both cases but the algorithms have to be adapted for real-time operation.

\section{References}

[1] http://www.piwg.org/sensor/sensor_btdeflection.html

[2] A European Lab Gap Matrix. European Virtual Institute for Gas Turbine Instrumentation

[3] J. S. Wilson. "Sensor Technology Handbook", Newnes, ISBN-13: 978-0750677295 (2004).

[4] E. Rokicki, R. Przysowa, J. Spychała, R. Szczepanik, M. Perz. "Electronic system of current inductive sensor, especially for measurement of flow blades vibrations of rotor machines", Polish patent PAT.209634 (2007). 
[5] R. Szczepanik, R. Przysowa, J.Spychała, E. Rokicki, K Kaźmierczak., P. Majewski "Application of Blade-tip Sensors to Blade-Vibration Monitoring in Gas Turbines" in: Thermal Power Plants. ISBN 978-953-307952-3. InTech - Open Access Publisher. Rijeka. Croatia (2011)

[6] E. Rokicki, J. Spychala, R. Szczepanik, P. Majewski. "Measuring vibrations of a turbo-machine rotor blade with the help of an induction sensor in high temperature". US 8125215 B2 (2009).

[7] R. Przysowa, J. Spychała, Health Monitoring of Turbomachinery Based on Blade Tip-Timing and Tip-Clearance, RTO-MP-AVT-157-14, 2008

[8] K. Chana Engine Experience of Non-optical Tip Timing Sensors in: Tip timing and tip clearance problems in turbomachinery, Lecture Series, von Karman Institute for Fluid Dynamics, VKI-LS-2007.

[9] R. Przysowa Analysis of synchronous blade vibration with the use of linear sine fitting, Journal of KONBiN, 2(30), pp. 5-20, De Gruyter Open (2014).

[10] R. Tomassini, JF Brouckaert, G. Rossi Contactless magnetoresistive sensor for tip timing and tip clearance measurement systems STO-MP-AVT-229-14 (2015).

[11] M. Witos, R. Szczepanik "Turbine Engine Health/Maintenance Status Monitoring with Use of Phase-Discrete Method of Blade Vibration Monitoring" RTO-MP-AVT-121-02 (2005).

[12] R. Przysowa, J. Spychała "Health Monitoring of Turbomachinery Based on Blade Tip-Timing and Tip-Clearance". RTO-MP-AVT-157-P14. Montreal (2008).

[13] RJ Morris, JW Littles, B. Hall, WD Owen, S. Tulpule, R. Szczepanik, R. Przysowa "Crack Detection and Prognosis Using Non-Contact Time of Arrival Sensors for Fan and Compressor Airfoils In Gas Turbine Engines" AeroMat (2009).

[14] K. Chana, D. Cardwell, L. Gray, B. Hall, "Disk Crack Detection And Prognosis Using Non-Contact Time Of Arrival Sensors". GT2011-45158.

[15] R. Przysowa, E. Rokicki, P. Majewski Optimized magnetic sensors to measure speed and position in adverse environments. IET \& ISA 60th International Instrumentation Symposium (2014). DOI: 10.1049/cp.2014.0552

[16] R. Przysowa, E. Rokicki, P. Majewski Health monitoring of industrial fan blades. 6th EVI-GTI International Gas Turbine Instrumentation Conference, Baden, CH; 11/(2013).

[17] M. Witoś, High sensitive methods for health monitoring of compressor blades and fatigue detection. TheScientificWorldJournal, 2012, 2013: 218460218460

[18] P. Russhard Derived Once per Rev Signal generation for Blade Tip Timing Systems. IET \& ISA 60th International Instrumentation Symposium, paper 5.1 (2014). 
Inductive sensors for blade tip-timing in gas turbines

Czujniki indukcyjne do pomiaru drgań topatek $w$ turbinach gazowych

[19] T. Nicholas. High cycle fatigue: a mechanics of materials perspective. Elsevier (2006).

[20] M. Zielinski, G.Ziller Noncontact Blade Vibration Measurement System for Aero Engine Application. 17th International Symposium on Airbreathing Engines, Munich, ISABE-2005-1220.

[21] B. Hayes (chair) ANSI/ISA-107.1-2013 Industry Standard File Format for Revolution-Based, Tip Timing Data, www.isa.org

[22] O. Jousselin, P.Russhard A method for establishing the uncertainty levels for aero-engine blade tip amplitudes extracted from blade tip timing data, 10th International Conference on Vibrations in Rotating Machinery - IMECHE, London (2012).

[23] P. Russhard BTT Data Zeroing Techniques, MFPT and ISA's 59th International Instrumentation Symposium (2013).

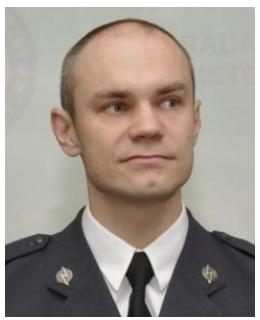

dr Radostaw Przysowa is involved in supporting machine maintenance since 2002. He is also familiar with research management and commercialization and has remarkable programming skills, including object oriented programming, digital signal processing and data mining. He specializes in Blade Tip-timing, which is a non-contact vibration measurement method, involving processing of aliased displacement signals.

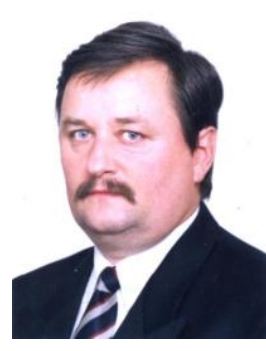

dr inż. Edward Rokicki ukończyt Politechnike Warszawska. W roku 2012 uzyskat w ITWL tytut doktora nauk technicznych. Jest wspóttwórca siedmiu polskich patentów oraz dwóch amerykańskich. Specjalizuje sie $w$ budowie indukcyjnych czujników wysokotemperaturowych do pomiaru drgań topatek oraz dedykowanych uktadów do kondycjonowania i rejestracji sygnatów. Prowadzi badania w obszarze wibroakustyki, stosujac m.in. metode tip-timing oraz zaawansowane algorytmy (statystyczne, neuronowe, agentowe, rozmyte, mrówkowe) w budowanych systemach sterujacych i diagnostycznych. 